\title{
PEMBERDAYAAN MASYARAKAT MELALUI PENERAPAN TEKNOLOGI KARBONASI SAMPAH ORGANIK UNTUK MENGATASI PERMASALAHAN LINGKUNGAN DAN ENERGI DI BOYOLALI
}

\author{
Danar Susilo Wijayanto, Deni Andriyansyah, Siti Nurrohmah, Latifah Nurul Q., \\ Wijayasari D.W., Krisnawan Suko Raharjo, Abdul Aziz Nur R., Erni Latifah W., \\ Susy Ermawaty, Athia Tamyizatun N, dan Amin Marlinda C. \\ Prodi Pendidikan Teknik Mesin, Jurusan Pendidikan Teknik dan Kejuruan, FKIP, UNS \\ Kampus UNS Pabelan J1. Ahmad Yani 200, Surakarta, Telp/Fax 0271718419 \\ email : danarsw@yahoo.com
}

ABSTRACT

KKN-PPM program objectives are : (1) Increase awareness and empathy students to weak economy community problems, resulting in a change in behaviour of students, intuitions and the target group, in this case is the Dibal village community by KKN-PPM programs, (2) Solve environmental problems caused by waste in the Dibal village and create a clean and comfortable environment with environmentally concious socialization and support go green movement, (3) Implementing technology carbonated organic waste into bio-briquettes as an alternative fuel in Dibal village.

KKN-PPM activities carried out with of continuous activities series, namely : (1) disseminasion to Dibal community, (2) Procurement of bio-briquette maker equipment : carboning drum, pail, smoothing tool/sieve/strainer, mixer, bio-briquette mold machine, and stove, (3) Training how to make bio-briquette, (4) training how to use bio-briquette.

The program implementation results are : (1) Dibal community continuosly able to utilize waste into environmental issues as an alternative fuel through pyrolysis combustion technologies such as bio-briquette, (2) Establishment of the independence of the target communities in managing organic waste into alternative fuel bio-briquette, (3) Dibal villagers applying bio-briquette as an alternative fuel.

Keywords : KKN-PPM, bio-briquette, organic waste, waste carbonation, community empowerment

\section{PENDAHULUAN \\ Latar Belakang}

Sampah merupakan hal yang tak bisa lepas dari kehidupan kita, karena setiap hari kita membuangnya baik di rumah, di kantor, dan dimanapun kita berada. Tidak heran jika keberadaannya dapat menimbulkan pencemaran tanah, air dan udara. Berdasarkan perhitungan BAPPENAS dalam buku infrastruktur Indonesia pada tahun 1995 perkiraan timbulan sampah di Indonesia sebesar 22,5 juta ton dan akan meningkat lebih dari dua kali lipat pada tahun 2020 menjadi 53,7 juta ton. Sementara di kota besar produk sampah perkapita berkisar antara 600-830 gram per hari.

Salah satu alternatif penanganan sampah adalah dengan pembakaran pirolisis dari sampah organik. Proses ini akan menghasilkan padatan (char) berupa arang dan berupa cairan (tar) yang memiliki nilai kalor tinggi. Char dapat diproses lanjut menjadi briket bio arang dan menjadikan energi alternatif. Selain itu, cara ini juga memberikan kontribusi dalam mengurangi jumlah sampah yang ada. Pembuatan briket bio arang merupakan salah satu upaya mewujudkan kebijakan pemerintah yang dilahirkan sebagai konsekuensinya kenaikan harga BBM.

Berdasarkan data BPPT tahun 2009, penggunaan energi terbarukan (renewable energy) seperti biogas, bioetanol, fuel cell dan sebagainya masih menempati persentase yang sangat kecil. Konsumsi energi hingga saat ini masih didominasi oleh minyak bumi. Konsumsi minyak bumi mencapai $54 \%$, sedangkan bentuk sumber energi lainnya di bawah $30 \%$.

Di desa Dibal, banyak terdapat lahan luas yang dimiliki warga, berupa area persawahan dan perkebunan pribadi. Sawah ditanami dengan pepadian, sedangkan kebun umumnya ditanami dengan tumbuhan yang menghasilkan bahan yang dapat dikonsumsi seperti buah-buahan dan sayuran. Selain menghasilkan produk yang bermanfaat, kebun tersebut juga banyak menghasilkan sampah, terutama sampah organik dari dedaunan kering. Bahkan warga terbiasa membuang sampah rumah tangga ke kebun mereka. Setelah sampah menumpuk, sampah hanya akan dibakar percuma dan justru akan menimbulkan polusi karena asapnya yang mengudara. Mengingat hal ini, masyarakat Desa Dibal perlu dikenalkan dengan teknologi 
pemanfaatan sampah menjadi bahan bakar alternatif yang lebih bermanfaat yakni briket bio arang. Saat ini di desa Dibal sudah ada organisasi kemasyarakatan BKM (Badan Keswadayaan Masyarakat) Mandiri yang bergerak di bidang pemberdayaan masyarakat. BKM Mandiri selalu berusaha memberdayakan masyarakat desa/kemampuan masyarakat miskin dalam upaya penanggulangan kemiskinan malalui pengembangan kapasitas, penyediaan sumber daya, dan membudayakan kemitraan yang sinergis antara masyarakat dengan pelaku-pelaku pembangunan lokal lainnya. BKM Mandiri adalah milik seluruh masyarakat Desa Dibal dan bukan miliki pemerintah, perorangan atau kelompok masyarakat tertentu. BKM Mandiri ini bersifat otonom dalam nilai luhur universal kemanusiaan, tidak berafiliasi ke pihak manapun baik partai, golongan,suku, agama, dan pemerintah, karenanya setiap kebijakan yang diambil BKM Mandiri tidak diintervensi atau dipengaruhi pihak manapun juga. Melalui BKM Mandiri inilah diharapkan kegiatan pemberdayaan masyarakat melalui pengelolaan sampah organik akan lebih efektif dan menyasar kepada seluruh masyarakat desa Dibal.

Briket bio arang mudah dibuat dan menghasilkan nilai ekonomi. Pada umumnya, briket dijual Rp 2000 s/d 2500/kg. Bila tiap kilogram briket membutuhkan $10 \mathrm{~kg}$ sampah organik yang ketersediaannya sangat melimpah, maka petani briket akan mendapatkan banyak keuntungan. Dengan demikian pembuatan briket sampah organik dapat menjadi mata pencaharian yang sangat menjanjikan bagi masyarakat dan mampu mengurangi timbunan sampah yang berbahaya bagi kesehatan lingkungan. Selain itu usaha briket sampah ini akan mampu meningkatkan kesejahteraan masyarakat dan produk yang dihasilkan siap dipakai oleh masyarakat karena murah dan memenuhi standar kesehatan. Jadi teknologi pembakaran pirolisis ini sangat bermanfaat jika diaplikasikan di masyarakat.

\section{Tujuan}

Tujuan program KKN-PPM ini adalah :

1. Meningkatkan kepedulian dan empati mahasiswa kepada permasalahan masyarakat ekonomi lemah, sehingga terjadi perubahan perilaku mahasiswa, institusi dan kelompok sasaran yang dituju, dalam hal ini adalah masyarakat desa Dibal untuk dikembangkan oleh program KKN-PPM.

2. Mengatasi permasalahan lingkungan yang ditimbulkan oleh sampah di Desa Dibal dan menciptakan kondisi lingkungan yang bersih dan nyaman dengan sosialisasi sadar lingkungan dan mendukung gerakan Go Green.

3. Memberikan keterampilan hidup kepada masyarakat Desa Dibal dengan memanfaatkan sampah organik.

4. Menerapkan teknologi karbonasi sampah organik menjadi briket bio arang sebagai bahan bakar alternatif di Desa Dibal.

\section{Manfaat}

Manfaat pelaksanaan program ini adalah :

1. Masyarakat Desa Dibal secara berkesinambungan mampu memanfaatkan sampah yang menjadi permasalahan lingkungan sebagai bahan bakar alternatif melalui teknologi pembakaran pirolisis.

2. Terbentuknya kemandirian masyarakat sasaran dalam mengelola sampah organik menjadi bahan bakar alternatif briket bio arang.

3. Masyarakat bisa memproduksi briket bio arang secara berkelanjutan, sehingga meningkatkan perekonomian dan kesejahteraan masyarakat.

\section{Tempat dan Jadual}

1. Tempat Pelaksanaan KKN-PPM KKN-PPM dilaksanakan di Desa Dibal, Kecamatan Ngemplak, Kabupaten Boyolali, Propinsi Jawa Tengah.

2. Jadual Pelaksanaan

Pelaksanaan KKN-PPM selama tiga bulan, dari bulan Agustus 2012 s/d Oktober 2012.

\section{Program Kerja KKN-PPM}

Kelurahan Desa Dibal merupakan desa yang memiliki banyak potensi. Masyarakat di desa tersebut sebagian besar bermata pencaharian sebagai petani, pedagang, buruh, serta berwiraswasta. Desa ini terletak di Kecamatan Ngemplak, Kabupaten Boyolali yang merupakan daerah perbatasan dengan Kabupaten Karanganyar dan Kota Madya Surakarta. Ketersediaan lahan yang masih luas, ruang hijau yang terbuka, peternakan, perikanan, infrastruktur yang memadai, banyak juga dijumpai pengrajin anyaman, pedagang berbagai 
kuliner khas seperti dawet yang terkenal dengan Dawet Dibal dan sebagainya. Desa Dibal sudah memiliki organisasi kemasyarakatan berupa BKM (Badan Keswadayaan Masyarakat) Mandiri yang bergerak di bidang pemberdayaan masyarakat. BKM Mandiri selalu berusaha memberdayakan masyarakat desa/kemampuan masyarakat miskin dalam upaya penanggulangan kemiskinan malalui pengembangan kapasitas, penyediaan sumber daya, dan membudayakan kemitraan yang sinergis antara masyarakat dengan pelaku-pelaku pembangunan lokal lainnya. Selain itu desa ini merupakan desa yang strategis, yaitu dekat dengan Bandar Udara Adi Soemarmo dan Asrama Haji Donohudan.

Desa ini terletak pada daerah yang datar. Lahan yang dimiliki warga masih banyak dan rata-rata sangat luas. Proporsi lahan kosong masih jauh lebih banyak jika dibandingkan dengan lahan yang sudah dihuni. Dengan didukung tanah yang subur, lahan warga sebagian besar ditanami dengan berbagai macam tumbuhan. Selain dapat membantu masyarakat dalam memenuhi kebutuhannya,

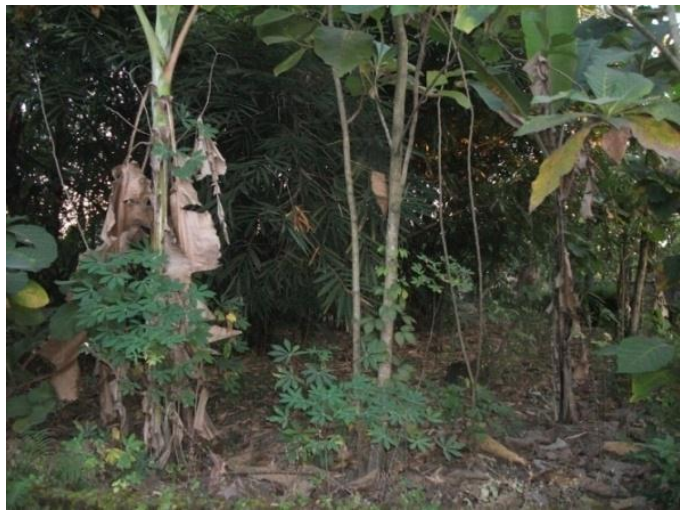

(a)Sampah Organik di Lahan Warga terkadang lahan kosong yang dimiliki warga dijadikan tempat pembuangan sampah. Warga membuangnya tanpa membedakan antara sampah organik dan sampah anorganik. Setelah sampah yang ada di lahan mereka menumpuk, mereka akan membersihkan lahan mereka dengan membakar sampah-sampah tersebut. Warga belum mengetahui potensi sampah untuk dijadikan bahan bakar, sehingga timbunan sampah yang ada hanya dipandang sebagai sesuatu yang negatif untuk dimusnahkan dan tidak dapat lagi dimanfaatkan. Selama ini, warga hanya mengenal daur ulang sampah anorganik saja. Pemanfaatan sampah organik, sejauh pengetahuan warga hanya dapat dimanfaatkan untuk membuat pupuk kompos. Pada kenyataannya, mereka juga kurang tertarik untuk membuat sampah menjadi kompos, karena faktor kesuburan tanah, mereka merasa tidak perlu memupuk tanaman di lahan mereka menggunakan kompos. Hal ini tentu saja sangat disayangkan karena sebenarnya sampah dapat diolah menjadi bahan bakar alternatif

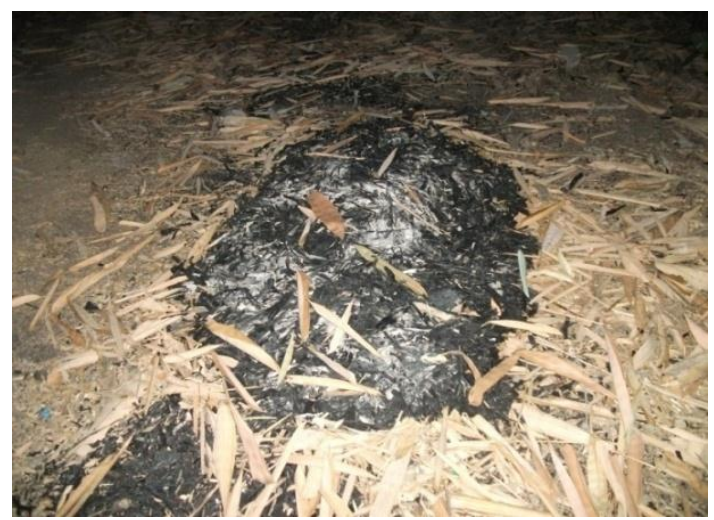

(b) Pembakaran Sampah oleh Warga

Gambar 1. Sampah Organik di Desa Dibal

Melihat permasalahan tersebut, Desa Dibal dengan badan pengelola masyarakatnya perlu diberikan bekal dalam rangka memberdayakan masyarakat setempat melalui pelatihan pembuatan suatu bahan alternatif dari sampah organik, sehingga mampu membantu masyarakat menangani permasalahan lingkungan. Kegiatan pelatihan diawali dengan melakukan sosialisasi kepada masyarakat mengenai pentingnya menjaga dan mengelola lingkungan, khususnya sampah organik yang bisa dimanfaatkan menjadi briket bio arang sebagai salah satu energi alternatif. Selanjutnya dilakukan pelatihan proses pemilihan sampah organik dan sampah non organik, lalu proses pembuatan briket bio arang, penggunaan briket bio arang sebagai bahan bakar memasak, serta pengembangan produk melalui pemasaran ke masyarakat sekitar. Pelatihan ini berlangsung dua tahap, yaitu tahap pembimbingan dan tahap mandiri. Tahap pembimbingan dilakukan di awal pelatihan, sedangkan tahap mandiri dilakukan oleh masyarakat sendiri tanpa ada bimbingan secara langsung dari tim KKNPPM. Tim KKN-PPM hanya memantau kegiatan masyarakat untuk melihat menyerap materi dan mempraktekkannya secara mandiri. Akhirnya dilakukan monitoring dan evaluasi 
terhadap kegiatan KKN-PPM ini sejauh mana kegiatan ini dalam mengatasi permasalahan sampah dan energi di lingkungan masyarakat desa Dibal. Di samping itu bahan bakar yang diciptakan akan mampu mengurangi ketergantungan warga terhadap bahan bakar minyak dan gas, atau bahkan bisa membantu menciptakan lapangan kerja baru bagi masyarakat sebagai petani briket bio arang. Jadi permasalahan energi juga bisa dipecahkan melalui program ini.

\section{METODE PELAKSANAAN KKN-PPM}

Metode pelaksanaan kegiatan ini akan dilakukan melalui beberapa tahap, yaitu:

\section{Persiapan dan Pembekalan}

a. Mekanisme pelaksanaan kegiatan KKN-PPM

1) Kegiatan rekruitmen mahasiswa sesuai dengan tugas dan peranan mahasiswa

2) Sosialisasi kepada masyarakat pengguna program KKN-PPM

3) Persiapan perlengkapan yang diperlukan dalam program KKN-PPM

4) Pembekalan mahasiswa peserta KKN-PPM

5) Pelaksanaan program KKNPPM di lokasi

6) Monitoring dan evaluasi kegiatan KKN-PPM di lokasi

7) Penarikan mahasiswa dari lokasi KKN-PPM

8) Evaluasi Program KKN-PPM

9) Pelaporan

b. Materi persiapan dan pembekalan KKN-PPM yang perlu diberikan kepada mahasiswa

Penjelasan kepada mahasiswa mengenai hal-hal yang perlu dipersiapkan sebelum melakukan kegiatan, yaitu :

1) Identifikasi Kondisi Masyarakat Sasaran

Pada tahap ini, tim melakukan survey lapangan dengan melakukan kunjungan kepada masyarakat sasaran untuk menggali informasi mengenai keadaan masyarakat sasaran secara lebih detail untuk menentukan solusi atas permasalahan secara cepat, tepat, taktis, efektif, dan efisien.

2) Perijinan :

a) Pelaksanaan kegiatan KKN-PPM melalui pemberdayaan masyarakat

b) Penggunaan Lahan dan Ruang Pelatihan serta kegiatan lainnya sehubungan dengan KKNPPM di Desa Dibal

3) Koordinasi

a) Koordinasi, baik antara sesama anggota tim, antara tim dengan dosen pembimbing senantiasa dilaksanakan selama persiapan kegiatan, saat pelatihan serta monitoring selama kegiatan ini berlangsung.

b) Koordinasi dengan masyarakat sasaran, khususnya dengan BKM Mandiri perihal kerja sama yang akan dibangun bersama dan segala hal yang terkait dengan kegiatan KKN-PPM.

4) Persiapan Alat dan Bahan Pelatihan

Alat yang digunakan dalam kegiatan KKN-PPM sebagai berikut:

a) Drum khusus pengarangan

b) Ember

c) Alat penghalus / ayakan / saringan

d) Alat pencampur adonan

e) Tungku pemanas

f) Mesin pencetak briket

Bahan yang digunakan dalam kegiatan KKN-PPM sebagai berikut:

a) Sampah organik

b) Tepung kanji

c) Air

5) Kegiatan KKN-PPM selama 1440 JKEM (jam kerja efektif mahasiswa) yang dilakukan oleh 10 (sepuluh) orang mahasiswa dengan dibimbing 
oleh seorang dosen selaku DPL.

\section{Pelaksanaan}

Kegiatan KKN-PPM dilaksanakan dengan beberapa kegiatan secara berkesinambungan, yaitu :

a. Tahap Implementasi Program melalui Pelatihan Pembuatan Briket Bio Arang

Pada tahap ini, tim melakukan pelatihan kepada masyarakat dan bersama masyarakat sasaran membuat briket bio arang dengan menggunakan proses karbonasi. Mengingat banyaknya jumlah dusun di desa Dibal, maka pelatihan dipusatkan menjadi dua lokasi. Masing-masing lokasi terdiri dari 50 orang warga yang merupakan perwakilan dari empat dusun. Pelatihan diawali dengan presentasi mengenai pentingnya mengelola lingkungan, khususnya sampah organik, serta kebutuhan energi alternatif berupa briket bio arang yang mudah dan murah. Metode ini dimaksudkan untuk menyadarkan masyarakat akan pentingnya memanfaatkan sampah organik agar menjadi barang yang memiliki nilai kegunaan maupun nilai ekonomis yang lebih tinggi dengan memanfaatkan sampah tersebut untuk pembuatan briket bio arang. Presentasi selanjutnya disampaikan bagaimana cara pembuatan briket bio arang. Pelatihan dilanjutnya dengan demonstrasi teknologi oleh tim dengan melibatkan peserta/masyarakat secara aktif. Teknologi tersebut meliputi :

1) Memotong salah satu sisi tutup drum berbentuk lingkaran kecil selebar $20 \mathrm{~cm}$ di tengah-tengah tutup ujung yang lain. Bagian tepi drum yang tajam dilekukkan ke bagian dalam.

2) Pengarangan menggunakan drum bekas yang dimodifikasi untuk pembakaran tidak sempurna agar diperoleh arang dari sampah organik berupa dedaunan dan ranting kering. Pengarangan ini dilakukan dengan cara mengisi drum dengan sampah organik tersebut. Selanjutnya membakar bahan-bahan tersebut dengan perlahan dan sekali-kali aduk dengan batang kayu melalui lubang atas drum. Jangan lupa memberikan percikan air untuk memperlambat proses pembakaran. Ketika semua bahan telah terbakar dan menjadi arang hitam, api dimatikan dengan air. Arang hitam akan tertinggal di bawah

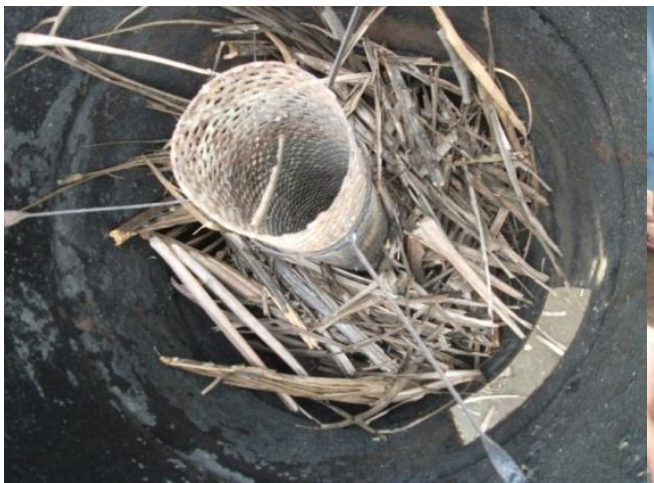

(a) Sampah Organik Dimasukkan ke dalam Drum Karbonasi

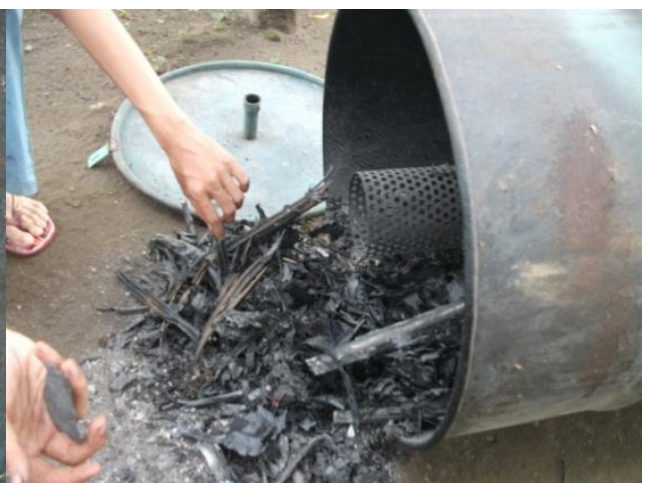

(b) Hasil Karbonasi Sampah

Gambar 2. Proses Pengarangan Sampah Organik

3) Penghancuran arang dengan menggunakan sapu lidi dan kayu agar diperoleh arang halus.
Arang yang sudah dihancurkan, selanjutnya disaring dengan menggunakan saringan. Arang 
halus diperoleh menggunakan saringan agar diperoleh ukuran butiran arang yang homogen.

4) Pembuatan adonan yang merupakan campuran antara arang halus hasil pembakaran (90\% sampai $95 \%)$ dan kanji (5\% sampai $10 \%$ ) serta air secukupnya hingga pulen. Arang yang telah dikeluarkan dari drum kemudian dihaluskan dengan cara ditumbuk. Arang kemudian diayak menggunakan penyaring agar partikel arang yang dihasilkan cukup halus dan homogen. Arang yang telah halus siap untuk dibuat adonan briket. Bahan yang digunakan untuk membuat adonan briket antara lain arang hasil karbonasi, tepung kanji, serta air. Mulamula dibuat perekat arang dengan cara melarutkan tepung kanji kedalam air mendidih sambil diaduk sehingga terbentuk lem kanji. Perbandingan yang digunakan untuk membuat lem kanji yaitu satu liter air untuk 15 sendok makan tepung kanji. Lem ini kemudian dicampur secara merata dengan arang dengan perbandingan 1 bagian lem kanji dan 3 bagian arang serbuk sehingga terbentuk adonan yang lunak dengan kandungan air yang rendah.

5) Pencetakan adonan menjadi briket dengan ukuran tertentu menggunakan mesin cetak dengan diameter 1 inch dan panjang $7 \mathrm{~cm}$. Langkah ini dilakukan dengan memasukkan hasil campuran antara arang hitam dengan perekat lem kanji ke dalam mesin pencetak briket bio arang, kemudian mesin dioperasikan. Sekali pencetakan menghasilkan 12 buah bio briket. Setelah pencetakan, briket basah dikeringkan dengan cara dijemur di bawah terik matahari hingga kering selama 1 x 24 jam.

6) Penggunaan bio briket sebagai bahan bakar. Kualitas bio briket sebagai bahan bakar dipengaruhi oleh jenis bahan baku dan kadar air bio briket serta tekanan pengempaan. Pengempaan dengan tekanan tinggi tidak selalu menghasilkan mutu briket yang lebih baik, karena bio briket yang sangat padat justru menurunkan efisiensi pembakaran dan menyulitkan penggunaan. Bio briket yang dihasilkan memiliki daya tahan pembakaran selama 1,5 hingga 2 jam berupa bara api. Penggunaan briket bioarang dalam kompor briket yang terbuat dari seng menghasilkan energi kalor yang cukup tinggi. Untuk mendidihkan 3 liter air dalam panci alumunium, dibutuhkan seperempat kilogram bio briket selama 25 s/d $30 \quad$ menit
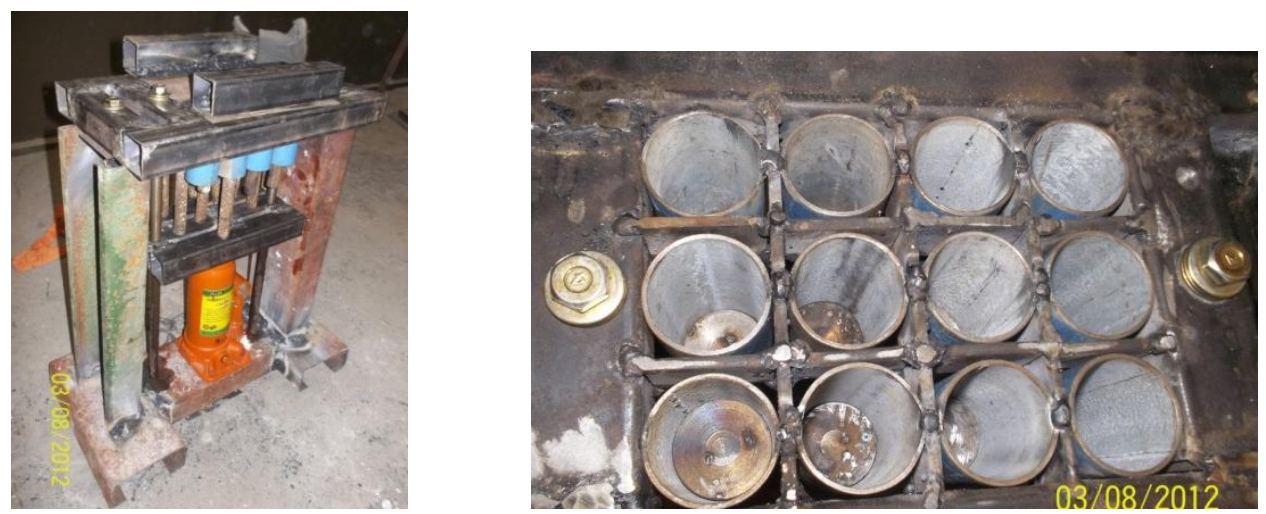

Gambar 3. Mesin Pencetak Bio Briket 


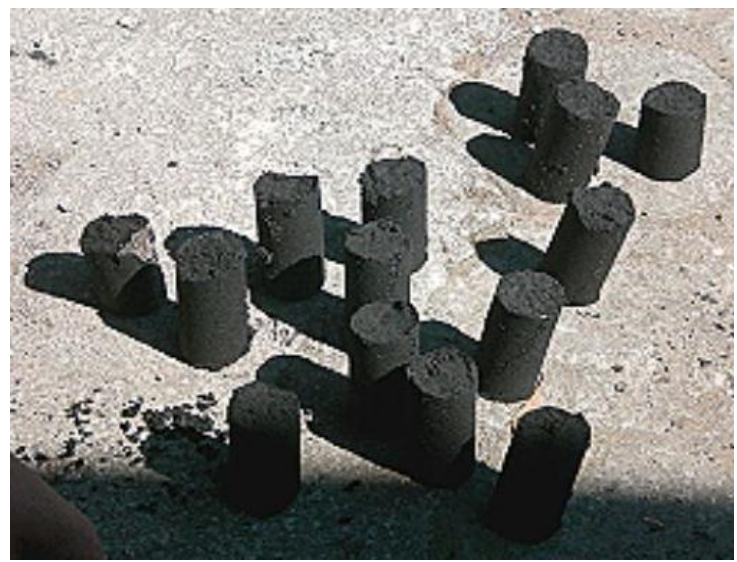

Gambar 4. Bio Briket

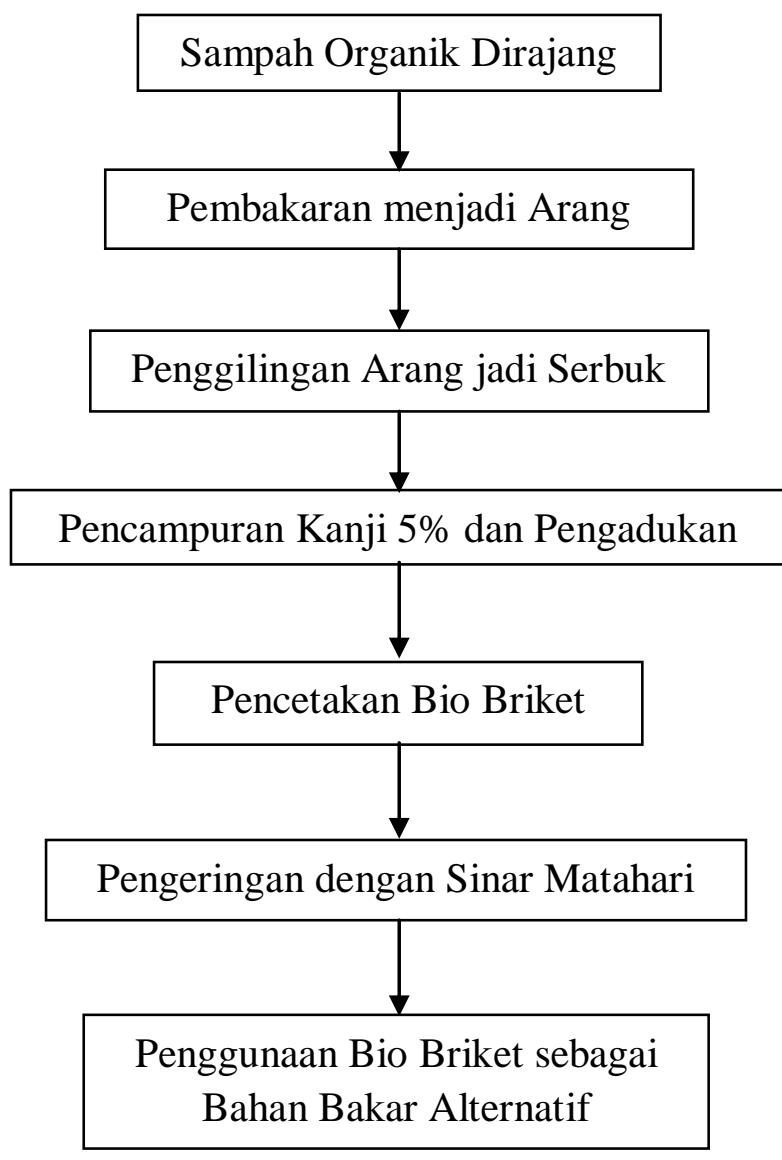

Gambar 5. Diagram Alur Pembuatan Briket Bio Arang

b. Pelatihan Cara Penggunaan Briket Bio Arang

Pada tahap ini tim melakukan sosialisasi bagaimana cara menggunakan briket bio arang sebagai bahan bakar.

Masing-masing kegiatan dilaksanakan menjadi dua tahap, yaitu : a. Tahap Pelaksanaan Kegiatan Masyarakat secara Terbimbing Kegiatan ini dilakukan pada saat tim melakukan pembimbingan secara intensif kepada masyarakat mengenai teknologi yang diterapkan dalam mengelola sampah organik. Kegiatan ini dilakukan sampai semua peserta/masyarakat bisa menerapkan 
dan mempraktekkan apa yang dilatihkan oleh tim.

b. Tahap Pelaksanaan Kegiatan Masyarakat secara Mandiri

Kegiatan ini dilakukan untuk memberikan kesempatan yang lebih luas kepada masyarakat untuk mempraktekkan apa yang sudah dilatihkan, mulai dari memisahkan antara sampah organik dengan sampah non organik, membuat briket dengan cara dan alat yang ada, menggunakan briket sebagai bahan bakar. Dalam hal ini masyarakat mencobanya atau melakukannya pada saat tidak bersama dengan pembimbing.

\section{HASIL DAN PEMBAHASAN KKN-PPM \\ 1. Pelaksanaan Program KKN-PPM}

Tahapan pelaksanaan program penerapan teknologi karbonasi ini dapat dijabarkan sebagai berikut :

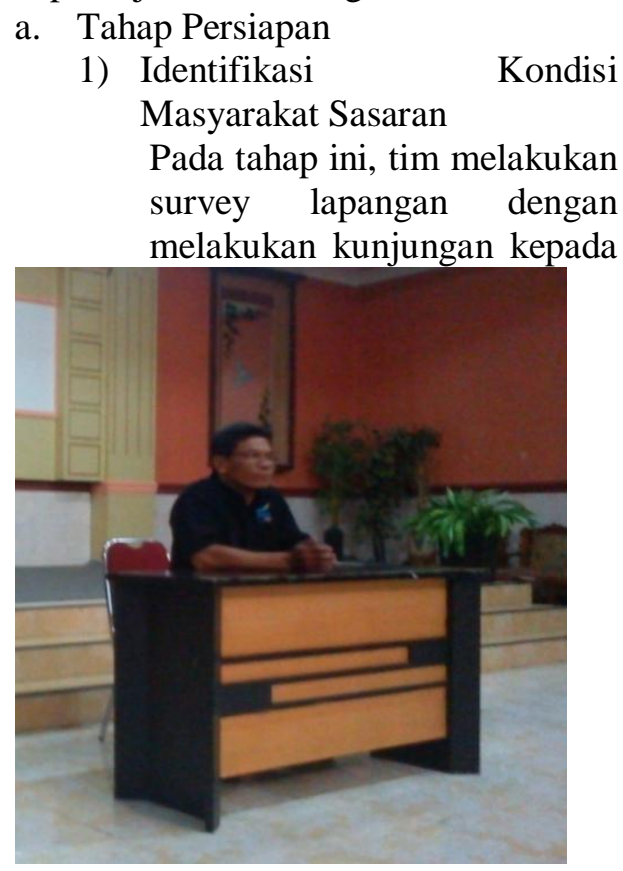

Ketua BKM Mandiri Memberikan Sambutan

Gambar 6. Sosialisasi di Desa Dibal

Pada tahap implementasi, ada sedikit kendala, yaitu pelaksanaan program di tingkat desa Dibal, tidak terlalu banyak masyarakat yang antusias dengan program masyarakat sasaran untuk mencari informasi mengenai keadaan masyarakat sasaran.

2) Perijinan

Pada tahap ini, perijinan dilakukan kepada Kepala Desa Dibal dan ketua BKM Mandiri desa Dibal.

3) Persiapan Alat dan Bahan

b. Tahap Implementasi Program

1) Sosialisasi program dilanjutkan pelatihan cara pembuatan bio briket

Pada tahap ini, tim melakukan pelatihan kepada masyarakat dan bersama masyarakat sasaran membuat briket bio arang dengan menggunakan proses karbonasi. Mengingat banyaknya jumlah dusun di desa Dibal, maka pelatihan dipusatkan menjadi dua lokasi. Masing-masing lokasi terdiri dari 50 orang warga yang merupakan perwakilan dari empat dusun. Lokasi tersebut adalah :

a) Balai Desa Dibal

b) Rumah Sdri. Latifah

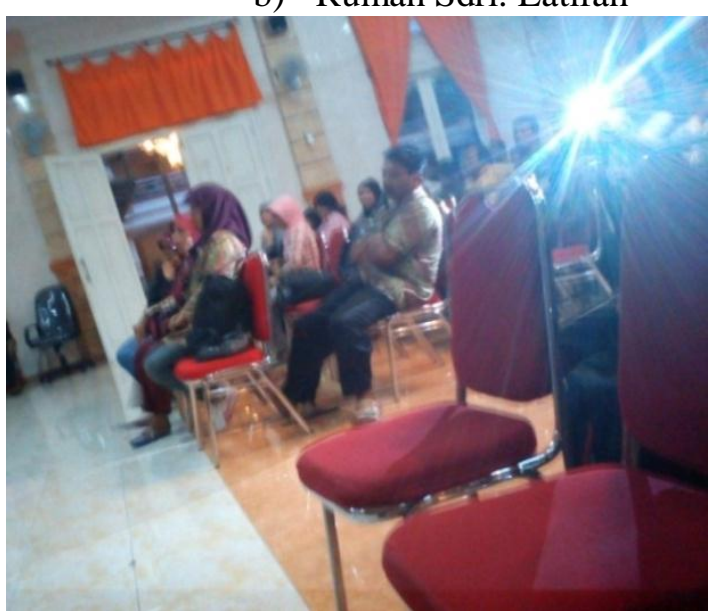

Sosialisasi dengan warga desa Dibal 
Pelaksanaan program di dusun Ngepreh berlangsung di rumah Sdri. Latifah, dengan alasan lokasinya ada di dusun tersebut. Masyarakat sangat

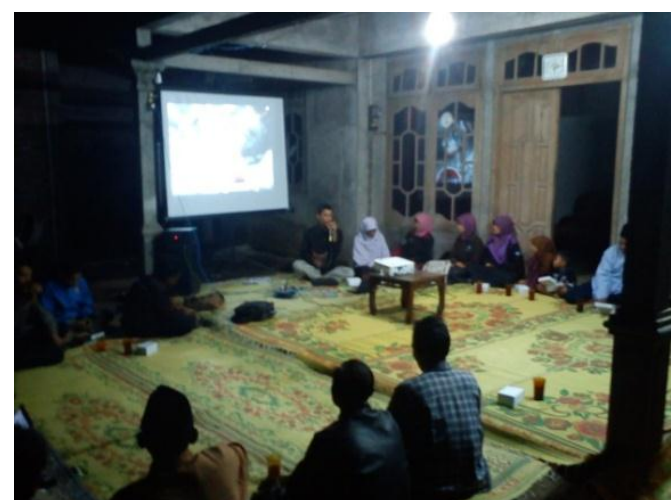

Tim Pelaksana sedang Presentasi antusias dalam mengikuti

kegiatan, mulai dari sosialisasi, sampai dengan pelatihan cara pembuatan bio briket.

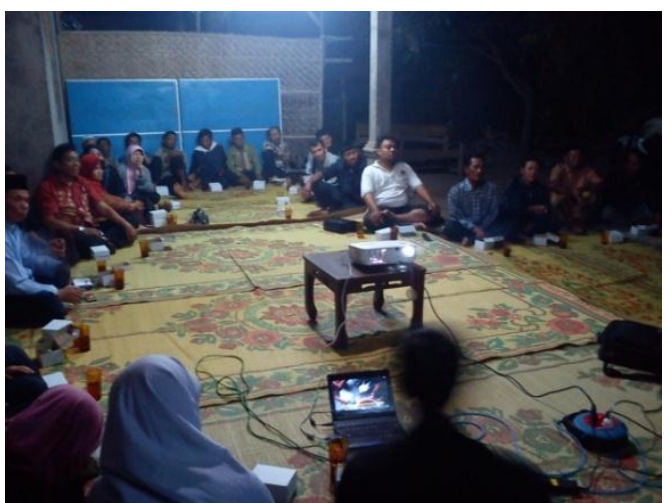

Suasana Sosialisasi Program

Gambar 7. Sosialisasi di Dusun Ngepreh

2) Pelatihan Cara Penggunaan Briket Bio Arang

Pada tahap ini tim melakukan sosialisasi bagaimana cara menggunakan briket bio arang sebagai bahan bakar. Banyak sekali warga dusun Ngepreh yang menginginkan untuk mencoba menggunakan briket bio arang di rumahnya. Tim pelaksana harus membagi tugas dengan baik agar kegiatan berjalan dengan lancar dan sukses.

Masing-masing kegiatan dilaksanakan menjadi dua tahap, yaitu :

1) Tahap Pelaksanaan Kegiatan Masyarakat secara Terbimbing

Kegiatan ini dilakukan pada saat tim melakukan pembimbingan secara intensif kepada masyarakat mengenai teknologi yang diterapkan dalam mengelola sampah organik. Kegiatan ini dilakukan sampai semua peserta/masyarakat dusun Ngepreh bisa menerapkan dan mempraktekkan apa yang telah dilatihkan oleh tim pelaksana.

2) Tahap Pelaksanaan Kegiatan Masyarakat secara Mandiri

Kegiatan ini dilakukan untuk memberikan kesempatan yang lebih luas kepada masyarakat untuk mempraktekkan apa yang sudah dilatihkan, mulai dari memisahkan antara sampah organik dengan sampah non organik, membuat briket dengan cara dan alat yang ada, menggunakan briket sebagai bahan bakar. Dalam hal ini masyarakat mencobanya atau melakukannya pada saat tidak bersama dengan pembimbing.

c. Tahap Pelaporan

Keseluruhan hasil implementasi program mulai dari persiapan hingga akhir dari program dilaporkan secara lisan di monitoring dan evaluasi, serta secara tulisan dalam bentuk laporan.

\section{Rencana Keberlanjutan Program}

Setelah selesai pelaksanaan program di atas, tim melakukan pelayanan kepada masyarakat dusun Ngepreh khususnya, dan Desa Dibal umumnya 
berupa bimbingan dan kosultasi untuk keberlanjutan program. Kegiatan ini dilakukan secara reguler, sehingga masyarakat dapat melakukan konsultasi secara optimal untuk perkembangan program. Selain itu, diberikan juga bimbingan perawatan alat yang digunakan dalam pembuatan briket.

\section{SIMPULAN DAN SARAN Simpulan}

Berdasarkan bab-bab sebelumnya di atas, kegiatan KKN-PPM ini dapat disimpulkan sebagai berikut :

1. Program pemberdayaan masyarakat melalui penerapan teknologi di Desa Dibal bisa membantu mengatasi permasalahan lingkungan yang ditimbulkan oleh sampah organik yang selama ini hanya menumpuk tidak termanfaatkan

2. Masyarakat Desa Dibal secara berkesinambungan mampu memanfaatkan sampah yang menjadi permasalahan lingkungan sebagai bahan bakar alternatif melalui teknologi pembakaran pirolisis berupa bio briket

3. Terbentuknya kemandirian masyarakat sasaran dalam mengelola sampah organik menjadi bahan bakar alternatif bio briket

4. Masyarakat Desa Dibal menerapkan bio briket sebagai bahan bakar alternatif pengganti bahan bakar yang lebih murah dan aman untuk dikonsumsi masyarakat.

\section{Saran}

1. Untuk kesinambungan penyediaan bio briket, khususnya pada proses pengeringan briket perlu menggunakan mesin pengering briket, agar pada musim penghujan pun pengeringan bio briket tetap bisa dilakukan secara maksimal.

2. Hendaknya anggota masyarakat lebih fokus dalam program ini, supaya proses produksi bio briket dapat berkelanjutan.

\section{DAFTAR PUSTAKA}

Bahar, Ir. Yul H. 1986. Teknologi Penanganan dan Pemanfaatan Sampah. Jakarta: PT Waca Utama Pramesti

Chandra, Budiman, 2007. Pengantar Kesehatan Lingkungan. Cetakan Pertama, Jakarta: Buku Kedokteran EGC

Dainur, 1995. Materi-Materi Pokok Ilmu Kesehatan Masyarakat. Cetakan Ketiga. Jakarta: Penerbit Widya Medika

Hadiwijoto, S. 1983. Penanganan dan Pemanfaatan Sampah. Jakarta: Yayasan Idayu

Holmes, C. dan Mutaqqien, R. 2007. Pembuatan Briket dari Serbuk Tempurung Kelapa dengan Penambahan Polietilen. Teknik Kimia, ITENAS.

Kartika, E. dan Paramita, S. 2007. Pembuatan Briket dari Sekam Padi Menggunakan Polyethylene sebagai Binder. Teknik Kimia, 